\title{
FORESTRY
}

DOI https://doi.org/10.30525/978-9934-26-111-4-63

\section{PRUNUS TENELLA (AMYGDALUS NANA) - АБОРИГЕННИЙ ПРЕДСТАВНИК ДЕНДРОФЛОРИ ЗАПОРІЗЬКОГО РЕГІОНУ}

\author{
Бойка О. А. \\ кандидат біологічних наук, \\ дочент кафедри генетики та рослинних ресурсів \\ Запорізький національний університет \\ м. Запоріжжя, Україна
}

Згідно Національного каталогу біотопів України [1, С. 133-135] більша частина Запорізького регіону розташовується у біотопі Т1.4 Справжні різнотравно-типчаково-ковилові та типчаково-ковилові степи підтипу Т1.4a - Справжні різнотравно-типчаково-ковилові та типчаково-ковилові степи степової зони.

Згідно міжнародних класифікацій біотопів та оселищ ці біотипи належать до:

1. EUNIS: E1.2D Ponto-Sarmatic steppes / Понтично-сарматські степи.

2. Резолюція 4 Бернської конвенції: E1.2 Perennial calcareous grasslands and basic steppes / Багаторічні трав'яні кальцифітні угруповання та степи.

3. Додаток I Оселищної Директиви: 62C0*Ponto-Sarmatic steppes / Понтично-сарматські степи; X18 Wooded steppe / Степи, що заростають лісом.

При описі цього типу біотипів зазначається, що одним 3 домінантів чагарникового ярусу є мигдаль степовий, або мигдаль низький, або мигдаль карликовий - Amygdalus nana, за новою систематикою Prunus tenella $[2,3]$.

Таксономічне (систематичне) положення цього виду є таким згідно останніх даних:

Kingdom Plantae

Phylum Tracheophyta

Class Magnoliopsida

Order Rosales

Family Rosaceae 
Scientific name Prunus tenella Bastch.

Також відомі назви його найрозповсюдженіших синонімів:

- Amygdalus georgica Desf.

- Amygdalus nana L.

- Prunus nana (L.) Stokes

Цей вид є диким родичом Prunus dulcis (Mill.) D. A. Webb, Prunus persica (L.) Batsch, Prunus domestica L., Prunus spinosa L., Prunus avium (L.) L.

Мигдаль степовий - це гіллястий листопадний чагарник, що досягає висоти до 1,5 метри. Листки в цієї рослини темно-зеленого кольору, прості, переважно лінійно-ланцентні, проте зустрічаються і широкоелептичні. Листкорозташування чергове. Квіти великі, яскраво-рожеві, типової будови для представників родини Розові, підродини Сливові. Основа маточки має опушення, тичинок багато, вони розташовуються у 2 кола. Квітне мигдаль степовий рано навесні. Генеративні бруньки розпускаються одночасно з вегетативними. Плід - кістянка зі стислою кісточкою.

На території Запорізького регіону мигдаль степовий розповсюджений по усій території, він формує невеликі куртини на степових відкритих ділянках, також, інколи зустрічається по краях байрочних лісів та на схилах ярів та балок.

Через своє ранньовесняне квітнення мигдаль степовий $€$ дуже важливим для бджіл та джмелів і $\epsilon$ однією 3 весняних медоносних рослин України. Також, він використовується людиною у якості лікарської рослини.

Мигдаль степовий - це не лише представник аборигенної дендрофлори Запорізького регіону, він до того ж широко використовується у якості декоративної рослини для озеленення територій через свій невеликий зріст та високу декоративність у весняний період.

У Свропи в природних угрупованнях мигдаль степовий зустрічається на території таких країн як Албанія, Австрія, Болгарія, Хорватія, Чехія, Угорщина, Молдова, Північна Македонія, Румунія, Російська Федерація (Центрально Свропейська Росія, Східно Європейська Росія, Південно Свропейська Росія), Сербія, Словакія.

На території Хорватії, Словакії та Угорщини він входить до переліку видів, що знаходяться під загрозою. Щодо інших країн то немає точних та повних даних щодо його природоохоронного статусу i це питання залишається відкритим та актуальним для проведення дослідження. Так само питання природоохоронного статусу цього виду 
на території України вивчено не в повному обсязі та вимагає додаткових досліджень.

Таким чином, можна зробити висновок, що мигдаль степовий належить до представників аборигенної дендрофлори Запорізького регіону, займає важливе місце у біоценозі справжніх різнотравнотипчаково-ковилових та типчаково-ковилових степів степової зони та дослідження ареалів зростання та розмірів його популяцій наразі $\epsilon$ актуальним та важливим для уточнення його природоохоронного статусу.

\section{Література:}

1. Винокуров Д.С., Дідух Я.П. Справжні різнотравно-типчаковоковилові та типчаково-ковилові степи. В кн.: Національний каталог біотопів України. За ред. А.А. Куземко, Я.П. Дідуха, В.А. Онищенка, Я. Шеффера. Київ : ФОП Клименко Ю.Я., 2018. С.133-135.

2. Amygdalus nana L. URL: https://www.gbif.org/uk/species/5369545

3. Wilson, B. 2018. Prunus tenella (errata version published in 2019). The IUCN Red List of Threatened Species 2018: e.T172171A159829407. https://dx.doi.org/10.2305/IUCN.UK.2018-2.RLTS.T172171A159829407. Downloaded on 28 June 2021. URL:https://www.iucnredlist.org/ species/172171/159829407 